
В.Б. Ніколаснко

\section{Мукорегулятор, антиоксидант, пневмопротектор - сучасне уявлення про місце ацетилцистеїну в терапії захворювань респіраторної системи}

Накопичені за останні десятиріччя дані експериментальних та клінічних досліджень дозволили суттєво розширити уявлення про механізми реалізації позитивних ефектів N-ацетилцистеїну при патології респіраторної системи. Плейотропний ефект препарату перш за все пов'язаний з антиоксидантною дією: прямою, яка реалізується завдяки наявності в молекулі тіольної групи, та непрямою, зумовленою підвищенням рівня глутатіону - ключового регулятора редокс-стану клітин. Крім того, N-ацетилцистеїн чинить мукорегуляторну, протизапальну, пневмопротекторну, антитоксичну, антимікробну дію. При гострих та хронічних захворюваннях респіраторної системи, які супроводжуються утворенням густого та гнійного мокротиння, N-ацетилцистеїн сприяє покращенню функції легень, позитивній динаміці клінічних проявів, зниженню частоти загострень хронічних респіраторних захворювань, поліпшує фізичну працездатність та якість життя пацієнтів. Антитоксичний, нефро- та гепатопротекторний ефекти та особливості фармакокінетики визначають добру переносимість N-ацетилцистеїну та низьку частоту побічних реакцій, навіть при тривалому прийомі у високих дозах.

Ключові слова: N-ацетилцистеїн, респіраторна система, мокротиння, оксидативний стрес, муколітик, антиоксидант, пневмопротекція, запалення, бронхіт, пневмонія, хронічне обструктивне захворювання легень, муковісцидоз, фіброзуючий альвеоліт, туберкульоз.

\section{Особливості фармакокінетики}

ацетилцистеїну

$\mathrm{N}$-ацетилцистеїн (N-acetylcysteine) є низькомолекулярною гідрофільною сполукою синтетичної природи - модифікованою формою амінокислоти цистеїну, до цистеїнового залишку якої приєднана ацетильна група (DrugBank, 2018). Препарат швидко абсорбується після перорального прийому та досягає піку концентрації в плазмі крові через 1-3 год (De Caro L. et al., 1989; Компендиум - лекарственные препараты, 2017). Час напіввиведення становить приблизно 2,5 год і визначається насамперед швидкістю біотрансформації в печінці з утворенням фармакологічно активного L-цистеїну - прямого попередника синтезу внутрішньоклітинного глутатіону, а також діацетилцистеїну, цистину і змішаних дисульфідів (De Caro L. et al., 1989). Препарат розподіляється в організмі як у незміненому вигляді (20\%), так і у вигляді активних метаболітів (80\%). Невеликий розмір та проста будова молекул надають N-ацетилцистеїну можливість легко проникати через клітинні мембрани та бути задіяним у великій кількості біохімічних реакцій. Найбільший вміст препарату визначають у тканині легень, бронхіальному секреті, печінці та нирках. Через 10-12 год N-ацетилцистеїн повністю виводиться нирками у вигляді неактивних метаболітів (неорганічні сульфати, діацетилцистеїн), у хворих із легеневою та серцево-судинною патологією цей період може збільшуватися до 24 год. Підкреслимо, що N-ацетилцистеїн не накопичується в організмі і не спричиняє токсичної дії (Беляева Л.Е. и соавт., 2008). Таким чином, особливості фармакокінетики препарату створюють сприятливі передумови для його застосування при бронхолегеневих захворюваннях.

\section{Основні механізми плейотропного ефекту ацетилцистеїну}

Накопичені за останні десятиріччя дані експериментальних та клінічних досліджень дозволили суттєво розширити уявлення про механізми реалізації позитивних ефектів $\mathrm{N}$-ацетилцистеїну при патології респіраторної системи. За визначенням L. Calzetta та співавторів (2018), N-ацетилцистеїн є «плейотропним препаратом з гетерогенними фармакологічними характеристиками». Перш за все це муколітик прямої дії, здатний розріджувати густе та гнійне мокротиння. В експериментах in vitro продемонстровано, що тіольні (сульфгідрильні) групи N-ацетилцистеїну, гідролізуючи дисульфідні зв'язки, що об'єднують мономери глікопротеїнів муцину в олігомери, знижують в'язкість і еластичність гелевої фази слизу та розріджують його без суттєвого збільшення обсягу.

Перш за все, ацетилцистеїн - це муколітик прямої дії, здатний розріджувати густе та гнійне мокротиння без суттєвого збільшення обсягу.

Відзначимо, що аеробне середовище та велика площа поверхні для газообміну роблять клітини епітелію дихальної системи особливо вразливими до оксидативного стресу - надлишок активних форм кисню (АФК) ендогенного або екзогенного походження в умовах дефіциту антиоксидантів може призвести до активації перекисного окиснення ліпідів, протеїнів, нуклеїнових кислот та подальшої загибелі клітин (Martindale J.L., Holbrook N.J., 2002; Dekhuijzen P.N., van Beurden W.J., 2006). Присутність у молекулі $\mathrm{N}$-ацетилцистеїну вільної нуклеофільної тіольної групи, здатної безпосередньо взаємодіяти з електрофільними групами окисних радикалів, відповідає і за його пряму антиоксидантну активність. Найефективніше N-ацетилцистеїн нейтралізує гідроксильні радикали $\left(\mathrm{OH}^{-}\right)$, перекис водню $\left(\mathrm{H}_{2} \mathrm{O}_{2}\right)$ і гіпохлорит-аніони $\left(\mathrm{OCl}^{-}\right)$, є «скавенджером» активних форм азоту - оксиду азоту (NO) та пероксинітриту (ONOO-), що дозволяє протистояти не лише «окисному», але й «нітрозилюючому» стресу.

Крім того, N-ацетилцистеїн спроможний хелатувати іони важких металів, таких як кадмій, ртуть та свинець, що полегшує їх видалення з організму у вигляді комплексів (Беляева Л.Е. и соавт., 2008; Соодаева С.К. и соавт., 2015; Pei Y. et al., 2018). Здатність відновлювати окиснені сульфгідрильні групи органічних сполук в реакціях обміну «тіол - дисульфід» зумовлює застосування $\mathrm{N}$-ацетилцистеїну як антидоту при інтоксикаціях речовинамиокиснювачами - парацетамолом, альдегідами, фенолами.

Непряма антиоксидантна дія $\mathrm{N}$-ацетилцистеїну зумовлена наявністю в його структурі цистеїнового залишку, який гідролізується до цистеїну та використовується для синтезу відновленого глутатіону (GSH) - трипептиду, до складу якого, окрім цистеїну, входять гліцин та ү-глутамінова кислота. Завдяки значній внутріш- 
ньоклітинній концентрації, надзвичайно високій біохімічній активності та здатності відновлювати інші антиоксиданти глутатіон постає як ключовий антиоксидант внутрішньоклітинної окисновідновної (редокс) системи. Водночас він є найважливішим компонентом системи детоксикації ксенобіотиків (Dekhuijzen P.N., van Beurden W.J., 2006; Соодаева С.К. и соавт., 2015). Оскільки епітелій респіраторного тракту формує перший бар'єр на шляху потрапляння в організм аерополютантів та екзогенних АФК, не випадково, що саме в його клітинах (а також в еритроцитах та гепатоцитах) виявляється найбільш високий вміст GSH.

Співвідношення між окисненим і відновленим глутатіоном надзвичайно важливе для регуляції напрямку реакцій окиснення/ відновлення активних сульфгідрильних груп специфічних протеїнів («редокс-сенсорів») і здатне впливати на функціональні властивості багатьох клітинних ферментів, факторів транскрипції, рецепторів, клітинних протоонкогенів, білків теплового шоку, молекул адгезії, цитокінів, структурних білків, білків іонних каналів та ін. (Беляева Л.Е. и соавт., 2008; Parasassi T. et al., 2010; Pizzorno J.E., Katzinger J.J., 2012). Втрата внутрішньоклітинного редоксгомеостазу призводить до ініціювання S-глутатіоляції - утворення S-кон'югатів окисненого глутатіону з реакційноздатними цистеїнами білків та формування змішаних дисульфідів, що стає сигналом для активації апоптотичного каскаду (Circu M.L., Aw T.Y., 2012; Pizzorno J.E., Katzinger J.J., 2012).

Єдиним фактором, що обмежує швидкість синтезу GSH, є внутрішньоклітинна кількість цистеїну, тому застосування в терапії $\mathrm{N}$-ацетилцистеїну можна вважати ефективною стратегією відновлення цього антиоксиданту (Parasassi T. et al., 2010). Крім того, $\mathrm{N}$-ацетилцистеїн здатний стимулювати активність глутатіон-Sтрансферази та глутатіонсинтетази, може виступати в ролі активатора цистеїн/глутаматного транспортеру, а збільшення внутрішньоклітинного вмісту $\mathrm{N}$-ацетилцистеїну сприяє витісненню глутатіону зі змішаних глутатіонвмісних дисульфідів (Mårtensson J. et al. 1989). На думку багатьох дослідників, саме вплив на глутатіонзалежні механізми редокс-регуляції клітинних функцій опосередковує учать $\mathrm{N}$-ацетилцистеїну в процесах внутрішньоклітинної сигналізації, регуляції функції мітохондрій, експресії генів, проліферації клітин та запобіганні апоптозу (Беляева Л.Е. и соавт., 2008; Parasassi T. et al., 2010; Pizzorno J.E., Katzinger J.J., 2012).

Пряма та непряма (глутатіонопосередкована) антиоксидантна активність ацетилцистеїну обумовлює його здатність протистояти оксидативному стресу та викликаній ним загибелі клітин епітелію дихальної системи.

Процеси оксидативного стресу та запалення тісно взаємопов'язані. Зокрема, цитокіни стимулюють синтез АФК та інших оксидантів, а ті, в свою чергу, беруть участь в активації редоксчутливих ядерних факторів транскрипції - нуклеарного фактора (nuclear factor kappa B - NF-kB) та білка-активатора AP-1. Хибне коло замикає експресія генів прозапальних протеїнів, ініційована активацією NF-kB, та збільшення синтезу цитокінів та інших медіаторів запалення, в тому числі C-реактивного білка (Zafarullah M. et al., 2003; Dekhuijzen P.N., van Beurden W.J., 2006). Тому цілком закономірно, що головними шляхами реалізації протизапальної дії N-ацетилцистеїну визнають:

- блокування експресії NF-kB - за рахунок опосередкованого серинкіназою інгібування $\alpha$ - та $\beta$-субодиниць NF-кB; пригнічення убіквітинування та деградації I-кB (інгібітору NF-кB, який блокує його ядерну транслокацію і активацію); зменшення внутрішньоклітинного вмісту активуючих NF-kB сигнальних молекул, в першу чергу АФК;

- пригнічення активності прозапальних цитокінів, насамперед інтерлейкіну-1 $\beta$, -6 та -8, фактора некрозу пухлини (tumor necrosis factor - TNF)- а і трансформуючого фактора росту- $\beta$;

- пригнічення стимульованої хемокінами (продуктами перекисного окиснення ліпідів та АФК) активації та міграції запальних клітин (нейтрофілів, лімфоцитів, моноцитів/макрофагів) у вогнище запалення (Oka S. et al., 2000; Sadowska A.M., 2012; PeiY. et al., 2018).

Результати одного з нещодавно опублікованих експериментальнихдослідженьпідтвердилипротективнудію $\mathrm{N}$-ацетилцистеїну на клітини культури епітелію дихальних шляхів в умовах оксидативного стресу та стерильної прозапальної відповіді, викликаних дією екстракту цигаркового диму. Під впливом препарату відбувалися швидке зниження внутрішньоклітинних рівнів прозапальних цитокінів (інтерлейкіну-6 та -8) та АФК, а також часткова блокада продукції АФК в мітохондріях (Valdivieso Á.G. et al., 2018).

Здатність запобігати апоптозу лежить в основі пневмопротекторних властивостей ацетилцистеїну. Продемонстрована спроможність $\mathrm{N}$-ацетилцистеїну уповільнювати деструкцію легеневої тканини та розвиток емфіземи легень за рахунок зниження активності еластази та мієлопероксидази, впливу на продукцію лактоферину, забезпечення захисту антипротеазних ферментів (зокрема $a_{1}$-антитрипсину) від вільнорадикального окиснення, зниження хемоатрактантної активності нейтрофілів (Eklund A. et al., 1988). Як з'ясували S. Саі та співавтори (2009), in vivo при індукованому впливом тютюнового диму хронічному обструктивному захворюванні легень (ХОЗЛ) N-ацетилцистеїн зменшує легеневу деструкцію, емфізему та апоптоз альвеолярних клітин, частково відновлюючи секрецію фактора росту судинного ендотелію (vascular endothelial growth factor) та експресію рецептора VEGFR2.

Здатність запобігати апоптозу клітин дихальної системи лежить в основі пневмопротекторних властивостей ацетилцистеїну.

Муколітичну дію $\mathrm{N}$-ацетилцистеїну в умовах in vivo доповнює так званий клінінговий ефект препарату, зумовлений його мукорегуляторними властивостями та покращанням мукоциліарного кліренсу, що виникають в результаті:

- інгібування (редокс-регуляція) гіперплазії келихоподібних клітин та пригнічення NF-кB-залежної експресії гена муцину (MUC5AC); зменшення стимульованої АФК та еластазою нейтрофілів дегрануляції келихоподібних клітин;

- стимуляції пневмоцитів II типу з підвищенням утворення сурфактанту;

- відновлення активності циліарного епітелію дихальних шляхів;

- стимуляції вагусних рефлексів шлунка та легень, які покращують відхаркування мокротиння (Беляева Л.Е. и соавт., 2008; Sadowska A.M., 2012; Yan X. et al., 2017; Zhang Q. et al., 2018). Істотний клінінговий ефект сприяє поліпшенню функції легень та швидшій ліквідації проявів запалення в умовах бронхолегеневої патології, що робить $\mathrm{N}$-ацетилцистеїн препаратом вибору за наявності в'язкого, слизово-гнійного або гнійного мокротиння. Також він може бути рекомендований при станах, що супроводжуються дефіцитом $\alpha_{1}$-антитрипсину або зниженням синтезу сурфактанту (тривалий перебіг бронхіту, пневмонія, муковісцидоз).

N-ацетилцистеїн має істотний клінінговий ефект, що робить його препаратом вибору за наявності в'язкого, слизово-гнійного або гнійного мокротиння.

Описано власну бактерицидну активність $\mathrm{N}$-ацетилцистеїну проти Pseudomonas aeruginosa, Staphylococcus aureus, Enterococcus faecalis, Enterobacter cloacae, Staphylococcus epidermidis, Klebsiella pneumoniae, Haemophilus influenzae, Mycobacterium tuberculosis (Amaral E.P. et al., 2016; Landini G. et al., 2016; Teskey G. et al., 2018). Суттєва антимікобактеріальна дія N-ацетилцистеїну зумовлена не лише пригніченням оксидативного стресу в макрофагах людини, інфікованих Mycobacterium tuberculosis, але й прямою бактерицидною дією (Amaral E.P. et al., 2016). Поєднання препарату із субоптимальними рівнями антибіотиків першого ряду (ізоніазидом та рифампіцином) сприяло швидкому очищенню від мікобактерій гранульом, вирощених in vitro, підвищувало ефективність терапії, дозволяло знизити дози антибіотиків, необхідні для забезпечення мікобактеріального кліренсу. Мікобактерії не мають власного GSH, натомість вони синтезують альтернативний мікотіол, тому навіть фізіологічна концентрація GSH всередині макрофагів може порушувати окисно-відновний гомеостаз Mycobacterium tuberculosis, спричиняти інгібування їх росту та загибель (Teskey G. et al., 2018). Застосування $\mathrm{N}$-ацетилцистеїну, на переконання авторів, відкриває нові перспективи щодо зменшення токсичності протитуберкульознихпрепаратів, підвищення комплаєнсу, боротьби з появою нових антибіотикорезистентних штамів мікобактерій.

Існують повідомлення про те, що N-ацетилцистеїн знижує адгезію Haemophilus influenzae i Streptococcus pneumoniae до епітелію ротоглотки, перешкоджає колонізації та росту бактерій, поліпшує антиінфекційний захист і знижує частоту загострень (Riise G.C. et al., 
2000; Yan X. et al., 2017). Утворення бактеріями біоплівок дозволяе їм уникати дії системи імунного захисту, робить стійкими до антибактеріальних препаратів, сприяє формуванню антибіотикорезистентності (Roy R. et al., 2018). Руйнування зрілих біоплівок широкого спектра бактерій виявлено вже після 10-хвилинної обробки $\mathrm{N}$-ацетилцистеїном, а через 24 год їх життєздатність знижувалася на 99\% порівняно з контролем, при цьому препарат виявив значно вищу активність, ніж насичений розчин гідроксиду кальцію або $2 \%$ розчин хлоргексидину (Moon J.H. et al., 2016).

Систематичний аналіз, здійснений італійськими вченими, засвідчив потенційну роль $\mathrm{N}$-ацетилцистеїну як молекулиад'юванта для руйнування бактеріальних біоплівок з відмінним профілем безпеки та ефективності (Dinicola S. et al., 2014). Застосування препарату в поєднанні з антибіотиками різних груп сприяло збільшенню ї проникності до найглибших шарів біоплівок, ерадикації зрілих біоплівок та інгібуванню формування нових Автори припустили, що подібна комбінована терапія має великі перспективи щодо подолання актуальної проблеми антибіотикорезистентності.

$\mathrm{N}$-ацетилцистеїн має потенціал застосування в поєднанні з антибіотиками різних груп для руйнування бактеріальних біоплівок і подолання спричиненою ними стійкості до антибіотикотерапії.

У низці експериментальних робіт відзначено противірусну активність препарату при інфекціях, спричинених вірусом грипу, яка значною мірою залежала від особливостей окремих штамів вірусу (Hui D.S. et al., 2018). Оскільки центральною ланкою патогенезу грипу $є$ активація ендотеліальних клітин з розвитком так званої цитокінової бурі, то цілком закономірно, що більшість дослідників пов'язує противірусну дію $\mathrm{N}$-ацетилцистеїну насамперед з анти-NF-кВ властивостями та інгібуванням шляху мітоген-активованої протеїнкінази (mitogen-activated protein kinases MAPK) p38 (Geiler J. et al., 2010; Bustos T.C., Garigliany M., 2016). Показано, що N-ацетилцистеїн пригнічує продукцію прозапальних молекул в епітеліальних клітинах дихальних шляхів, інфікованих високопатогенними вірусами грипу А і B (Geiler J. et al., 2010; Hui D.S. et al., 2018). N-ацетилцистеїн продемонстрував синергізм з осельтамівіром щодо запобігання летальності лабораторних мишей, інфікованих вірусом грипу штаму A/PR/8 (H1N1): у групі комбінованої терапії виживання становило 100\% порівняно з 60\% при монотерапії осельтамівіром (Garozzo A. et al., 2007).

\section{$\mathrm{N}$-ацетилцистеїн при лікуванні респіраторної \\ патології в світлі доказової медицини}

Багаторічний досвід застосування $\mathrm{N}$-ацетилцистеїну беззаперечно підтвердив його репутацію як ефективного та безпечного муколітика прямої дії та антидота при лікуванні отруєнь ацетамінофеном, важкими металами та іншими речовинами, що дозволило Всесвітній організації охорони здоров'я включити його до переліку життєво необхідних лікарських засобів (WHO, 2017) Поєднання мукорегуляторних, антиоксидантних, протизапальних пневмопротекторних, антитоксичних властивостей робить цей препарат незамінним при лікуванні гострих та хронічних захворювань респіраторної системи, в патогенезі яких провідну роль відіграють оксидативний стрес, запалення та погіршення евакуації мокротиння.

На сьогодні $\mathbf{N}$-ацетилцистеїн застосовують в терапії пацієнтів дитячого та дорослого віку із гострим та хронічним бронхітом, пневмонією, ХОЗЛ, бронхіальною астмою, бронхоектатичною хворобою, муковісцидозом, ларинготрахеїтом, синуситом, захворюваннями середнього вуха та ін.

Додатковою перевагою $\mathrm{N}$-ацетилцистеїну є протидія негативному впливу аерополютантів, насамперед тютюнового диму та промислових забруднювачів атмосфери - основних етіопатогенетичних факторів ХОЗЛ та хронічного бронхіту (Соодаева С.К. и соавт., 2015). Тому невипадково значна кількість клінічних досліджень $\mathrm{N}$-ацетилцистеїну присвячена лікуванню саме цієї найпоширенішої середдорослих пацієнтів хронічної патології дихальних шляхів. Починаючи з січня 2003 р. регулярно оприлюднюються результати Кокрейнівських систематичних оглядів застосування муколітиків при ХОЗЛ та хронічному бронхіті; в останнє оновлення (Poole P. et al., 2015) включено результати 34 подвійних сліпих плацебо-контрольованих рандомізованих клінічних досліджень (РКД) з майже десятитисячною когортою пацієнтів (n=9367), у 19 з яких застосовували $\mathrm{N}$-ацетилцистеїн (в $11-$ в дозі 600 мг/добу).

Наймасштабнішим залишається проведене китайськими вченими багатоцентрове РКД PANTHEON, в яке включено 1006 пацієнтів віком 40-80 років із ХОЗЛ помірного та тяжкого ступеня. На початковому етапі хворі були стратифіковані відповідно до застосування інгаляційних кортикостероїдів (IKC) та рандомізовані для прийому протягом 1 року $\mathrm{N}$-ацетилцистеїну $(\mathrm{n}=504)$ в дозі 600 мг 2 рази на добу або плацебо (Zheng J.P. et al., 2014). У групі хворих, які отримували $\mathrm{N}$-ацетилцистеїн, відзначено зниження частоти загострень ХОЗЛ (1,16 загострення на 1 пацієнта проти $1,49$ в групі плацебо; відношення шансів 0,$78 ; p=0,0011)$, при цьому найбільш виражений позитивний ефект препарату виявлено у пацієнтів із помірною тяжкістюХОЗЛ. Важливо також, що частота побічних дій $\mathrm{N}$-ацетилцистеїну не перевищувала плацебо.

$\mathrm{N}$-ацетилцистеїн протидіє негативному впливу аерополютантів, насамперед тютюнового диму та промислових забруднювачів атмосфери - основних етіопатогенетичних факторів ХОЗЛ та хронічного бронхіту.

Хоча в іншому багатоцентровому проспективному РКД BRONCUS, в якому протягом 3 років спостерігали 523 пацієнтів із ХОЗЛ помірного та тяжкого ступеня, не продемонстровано значного впливу прийому N-ацетилцистеїну (в дозі 600 мг/добу) на середню частоту загострень, але в пацієнтів, які застосовували $\mathrm{N}$-ацетилцистеїн і не приймали IKC, коефіцієнт ризику загострень значно знизився (на $22 \%$; $p=0,040$ ) порівняно з плацебо. Більше того, вторинний аналіз результатів показав, що через 3 роки у хворих, які закінчили дослідження, функціональна залишкова ємність (functional residual capacity - FRC) зменшилася на 374 мл у групі N-ацетилцистеїну, тоді як в групі плацебо підвищилась на 8 мл $(p=0,008)$ (Decramer M. et al., 2005).

У РКД НІАСЕ встановлено, що застосування $\mathrm{N}$-ацетилцистеїну (в дозі 1200 мг/добу протягом 12 міс) в терапії 120 хворих зі стабільним перебігом ХОЗЛ сприяло суттєвій позитивній динаміці функції нижніх дихальних шляхів: на 50\% зросла швидкість форсованого видиху і показники, одержані за методикою вимушеної осциляції (forced oscillation techniques) (Tse H.N. et al., 2013). Також у пацієнтів групи $\mathrm{N}$-ацетилцистеїну відзначали суттєве зниження частоти загострень порівняно з плацебо $(0,96$ та 1,71 раза на рік відповідно; $p=0,019$ ) та тенденцію до зменшення частоти госпіталізацій $(0,5$ та 0,8 раза на рік відповідно; $p=0,169)$, пов'язаних із загостренням ХОЗЛ.

За даними D. Stav, M. Raz (2009), застосування N-ацетилцистеїну в дозі 1200 мг/добу протягом 12 тиж у пацієнтів з помірною та тяжкою ХОЗЛ сприяло позитивній динаміці показників функціональної здатності легень у спокої та після фізичного навантаження: збільшувалися ємність вдиху та форсована життєва ємність легень, зменшувалося співвідношення залишкового об'єму та загальної ємності легень (residual volume/total lung capacity - RV/TLC). Водночас хворі, які приймали препарат, продемонстрували більшу толерантність до фізичного навантаження. Отримані результати дозволили зробити висновок про сприятливий вплив $\mathrm{N}$-ацетилцистеїну на фізичну працездатність пацієнтів з помірною та тяжкоюХОЗЛ. Поліпшення функції легень пояснили зниженням під дією $\mathrm{N}$-ацетилцистеїну ступеня емфіземи у пацієнтів із ХОЗЛ за рахунок пригнічення синтезу еластази. Також відзначено добру переносимість тривалої терапії препаратом у високих дозах.

Суттєва позитивна динаміка клінічнихпроявів загострення ХОЗЛ (інтенсивності та частоти кашлю, аускультативних даних) та позитивнадинаміка маркерів системногозапалення (рівнів С-реактивного білка та інтерлейкіну-8) на тлі прийому $\mathrm{N}$-ацетилцистеїну в дозі 1200 мг/добу, на думку авторів італійського PKІ за участю 123 пацієнтів, чітко підтвердили муколітичний, антиоксидантний та протизапальний ефекти препарату (Zuin R. et al., 2005).

Бельгійські науковці представили результати цікавого дослідження з використанням нової методики візуалізації респіраторної функції, що поєднала мультиспіральну комп'ютерну томогра- 
фію та комп'ютерне моделювання структури повітряного потоку всередині дихальних шляхів із вимірюванням FRC та TLC (Backer J. et al., 2013). Виявлено достовірні кореляції між характеристиками опору дихальних шляхів, початковими рівнями глутатіонпероксидази в плазмі крові, їх динамікою в процесі лікування, рівнями глутатіону після лікування $\mathrm{N}$-ацетилцистеїном. Висловлено припущення, що комбінація методики візуалізації з дослідженням показників глутатіонпероксидази та глутатіону може бути використана для визначення фенотипу хворих та прогнозування ефективності $\mathrm{N}$-ацетилцистеїну при лікуванні ХОЗЛ.

Результати аналізу 11 РКД (Medline, Embase, Cochrane Library) в яких вивчали ефективність та безпеку застосування $\mathrm{N}$-ацетилцистеїну у 2011 пацієнтів із хронічним бронхітом, свідчили, що пероральний прийом $\mathrm{N}$-ацетилцистеїну протягом 12-24 тиж знижував ризик загострень і покращував симптоми у хворих на хронічний бронхіт порівняно з плацебо без підвищення ризику побічних ефектів. На основі отриманих результатів автори дослідження обґрунтували рекомендацію щодо рутинного тривалого застосування $\mathrm{N}$-ацетилцистеїну в усіх хворих на хронічний бронхіт (Stey C. et al., 2000).

В оновлених рекомендаціях Глобальної ініціативи з хронічного обструктивного захворювання легень (Global Initiative for Chronic Obstructive Lung Disease - GOLD) зазначено, що у пацієнтів із ХОЗЛ, які не отримують IKC, застосування муколітиків (мукокінетиків та мукорегуляторів) та антиоксидантів, у тому числі $\mathrm{N}$-ацетилцистеїну, може помірно покращувати стан здоров'я (Global Initiative for Chronic Obstructive Lung Disease, 2018). Гайдлайн AECOPD з ведення хворих із загостренням ХОЗЛ, підготований Американською колегією пульмонологів (American College of Chest Physicians - ACСР) спільно з Канадським торакальним товариством (Canadian Thoracic Society - CTS), рекомендує пероральний прийом N-ацетилцистеїну клінічно стабільним пацієнтам з середньою та тяжкою формами ХОЗЛ для запобігання загостренням та поліпшення якості життя (Criner G.J. et al., 2015).

Рекомендації Національного інституту здоров'я і досконалості допомоги (National Institute for Health and Care Excellence - NICE) 2018 р. з ведення пацієнтів із ХОЗЛ віком >16 років передбачають проведення муколітичної медикаментозної терапії (в тому числі $\mathrm{N}$-ацетилцистеїном) при хронічному кашлі з продукцією мокротиння. Ї̈̈ слід продовжувати лише за наявності симптоматичного поліпшення (наприклад зниження частоти кашлю та/або продукції мокротиння).

Значну увагу $\mathrm{N}$-ацетилцистеїну приділено в консенсусі щодо застосування мукоактивних та антиоксидантних препаратів при ХОЗЛ та хронічному бронхіті, запропонованому групою китайських експертів-пульмонологів на основі аналізу опублікованих даних 316 РКД (для підсумкового документа відібрано 66 посилань) (Yan X. et al., 2017). Наведені дані підтверджують, що застосування $\mathrm{N}$-ацетилцистеїну є безпечним і ефективним для профілактики та лікування загострень ХОЗЛ та хронічного бронхіту - препарат має мінімальні побічні ефекти та здатний чинити позитивний вплив на вираженість клінічних проявів, рівень маркерів системного запалення, показники функціональної здатності легень, толерантність до фізичного навантаження, частоту загострень, частоту та тривалість госпіталізацій, загальне самопочуття та якість життя хворих Ґрунтуючись на цитованих дослідженнях та даних реальної клінічної практики, науковці рекомендували проводити довгострокову мукоактивну/антиоксидантну терапію протягом всього періоду наявності скарг на кашель із мокротинням або задишку у пацієнтів із хронічним бронхітом або ХОЗЛ. Вони припустили, що таке лікування показане хворим на ХОЗЛ з виявленими за допомогою комп'ютерної томографії бронхоектазами, або тим, у кого з дитинства наявні скарги на кашель із мокротинням.

Застосування $\mathrm{N}$-ацетилцистеїну є безпечним і ефективним для профілактики та лікування загострень ХОЗЛ та хронічного бронхіту - препарат має мінімальні побічні ефекти та здатний чинити позитивний вплив на вираженість клінічних проявів, рівень маркерів системного запалення, показники функціональної здатності легень, толерантність до фізичного навантаження, частоту загострень, частоту та тривалість госпіталізацій, загальне самопочуття та якість життя хворих.
Можливість впливу на основі ланки патогенезу позалікарняної пневмонії - оксидативний стрес та запалення - шляхом включення в терапію $\mathrm{N}$-ацетилцистеїну доведена в нещодавньому дослідженні Q. Zhang та співавторів (2018). У групі хворих, які додатково до стандартної терапії отримували $\mathrm{N}$-ацетилцистеїн в дозі 1200 мг/добу, спостерігали достовірне зниження рівнів малонового діальдегіду та TNF-a, а також підвищення загальної антиоксидантної активності (total antioxidant capacity). Також відзначено відсутність побічних ефектів при застосуванні $\mathrm{N}$-ацетилцистеїну.

За даними багатоцентрового рандомізованого подвійного сліпого плацебо-контрольованого дослідження IFIGENIA, у хворих на ідіопатичний легеневий фіброз пероральне застосування ацетилцистеїну (600 мг 3 рази на добу) протягом 1 року в поєднанні зі стандартною терапією (преднізолон та азатіоприн) мало суттєвий клінічно виражений ефект щодо збереження життєвої ємності легень та їх дифузійної здатності за даними тесту дифузійної здатності легень для моноокису вуглецю (diffusing capacity of the lung for carbon monoxide - DLCO) через 6 та 12 міс спостереження. Крім того, в групі $\mathrm{N}$-ацетилцистеїну достовірно рідше відмічали мієлотоксичні побічні ефекти імунодепресантів (Behr J. et al., 2009).

Застосування у хворих на муковісцидоз $\mathrm{N}$-ацетилцистеїну у високих дозах (1800-3000 мг/добу) протягом 4 тиж сприяло значному зменшенню кількості нейтрофілів та активності еластази в мокротинні, добре переносилося хворими і не призводило до розвитку ускладнень, що дозволило констатувати безпеку його застосування у високих дозах для тривалої терапії при муковісцидозі з метою протидії порушенням, викликаним спільною дією оксидативного стресу та запалення (Dauletbaev N. et al., 2009). В інших аналогічних дослідженнях у пацієнтів, які отримували $\mathrm{N}$-ацетилцистеїн, спостерігали підвищення рівня позаклітинного глутатіону в дихальних шляхах (Tirouvanziam R. et al., 2006), відзначали стабільність або поліпшення показників функції легень, тоді як в групі плацебо вони погіршилися (Conrad C. et al., 2015)

Слід враховувати доведену ефективність $\mathrm{N}$-ацетилцистеїну як засобу, що чинить гепато- та нефропротекторну дію (Onk D. et al., 2018), сприяє зменшенню токсичності лікарських препаратів, що є надзвичайно важливим при лікуванні хворих із поліморбідністю, які становлять більшість серед дорослих пацієнтів із хронічною легеневою патологією.

У педіатричній практиці найчастішим приводом для призначення $\mathrm{N}$-ацетилцистеїну $є$ гострі респіраторні захворювання - в більшості країн світу при виборі муколітика для лікування дитини перевагу надають саме цьому препарату.

До Кокрейнівського систематичного огляду досліджень, присвячених застосуванню ацетилцистеїну та карбоцистеїну в терапії гострих інфекцій верхніх та нижніх дихальних шляхів у дітей без хронічних бронхолегеневих захворювань, включено 34 РКД

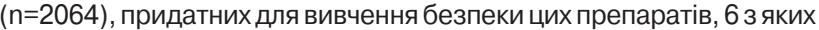
( $n=497)$ стали підставою для вивчення ефективності (Chalumeau M., Duijvestijn Y.C., 2013). Результати аналізу дозволили експертам констатувати здатність $\mathrm{N}$-ацетилцистеїну знижувати частоту, інтенсивність та тривалість симптомів гострого респіраторного захворювання, а також високу безпеку при застосуванні у дітей віком $>2$ років.

Таким чином, дані доказової медицини підтверджують можливість позитивної плейотропної дії $\mathrm{N}$-ацетилцистеїну при широкому спектрі захворювань респіраторної системи. Мукорегуляторний та муколітичний (клінінговий), антиоксидантний, протизапальний та пневмопротекторний ефекти препарату сприяють очищенню дихальних шляхів від мокротиння, покращенню функції легень, позитивній динаміці клінічних проявів та зменшенню частоти загострень хронічних респіраторних захворювань, підвищенню фізичної працездатності та покращенню якості життя пацієнтів. Перспективними напрямками можна вважати застосування $\mathrm{N}$-ацетилцистеїну при легеневому туберкульозі, бактеріальних захворюваннях, що супроводжуються утворенням біоплівок, зниженням синтезу сурфактанту, у пацієнтів з поліморбідністю. Антитоксичний, нефро- та гепатопротекторний ефекти та особливості 
фармакокінетики $\mathrm{N}$-ацетилцистеїну, в першу чергу відсутність накопичення в організмі та швидке перетворення більшої частини введеної дози в глутатіон - ключовий компонент антиоксидантної системи, визначають добру переносимість препарату та низьку частоту побічних реакцій навіть при тривалому застосуванні у високих дозах

\section{ЕВКАБАЛ ${ }^{\circledR}$ САШЕ - європейська якість}

\section{ацетилцистеїну}

Як зазначено вище, $\mathrm{N}$-ацетилцистеїн являє собою достатньо високоактивну в біо- та електрохімічному плані молекулу, тому великого значення для збереження ефективності діючої речовини набуває ретельне дотримання технологічних умов при виробництві фармакологічних препаратів, які його містять. При виборі препарату $\mathrm{N}$-ацетилцистеїну слід віддавати перевагу надійним, перевірений часом виробникам. До їх числа входить німецька компанія «Еспарма», яка за багаторічну працю на фармацевтичному ринку України заслужила довіру лікарів, пацієнтів та провізорів. Ї̈̈ добре відому серію ЕВКАБАЛ нещодавно поповнив новий препарат, активною речовиною якого $є$ ацетилцистеїн, - ЕВКАБАЛ ${ }^{\oplus}$ САШЕ.

ЕВКАБАЛ ${ }^{\circledR}$ САШЕ випускається у формі порошку для приготування орального розчину в двох дозуваннях -600 мг (для дорослих та дітей віком >14 років) та 200 мг (для дітей віком $>6$ років) Препарат володіє всіма властивостями, притаманними $\mathrm{N}$-ацетилцистеїну, і може з успіхом застосовуватися за наявності густого та гнійного мокротиння на тлі гострих і хронічних захворювань респіраторної системи у дітей віком >6 років та дорослих: при гострому та хронічному бронхіті, пневмонії, ХОЗЛ, бронхоектатичній хворобі, муковісцидозі, ларинготрахеїті, середньому отиті та ін. ЕВКАБАЛ ${ }^{\circledR}$ САШЕ чинить пряму муколітичну дію, сприяючи швидкому розрідженню та евакуації мокротиння з дихальних шляхів. Виражений клінічний ефект у вигляді зменшення інтенсивності кашлю проявляється вже на 3-тю добу від початку лікування. Препарат прискорює одужання, запобігає загостренням та скорочує їх тривалість, запобігає розвитку ускладнень, зменшує потребу в антибактеріальній терапії, а в разі ї̈ застосування підвищує ефективність антибіотиків. ЕВКАБАЛ ${ }^{\circledR}$ САШЕ може зменшувати гепатотоксичну дію парацетамолу, а при одночасному застосуванні з бронхолітиками посилює їх дію.

ЕВКАБАЛ ${ }^{\circledR}$ САШЕ - новий препарат ацетилцистеїну у герметичних пакетиках (саше) у формі порошку для приготування розчину безпосередньо перед вживанням. Його відрізняє висока німецька якість, засвідчена сертифікатом GMP (Good Manufacturing Practic) європейського зразка, та найкраще співвідношення ціна/якість.

Водночас ЕВКАБАЛ ${ }^{\circledR}$ САШЕ демонструє високий профіль безпеки, добре переноситься навіть при тривалому лікуванні. Він має приємний смак і зручний для застосування. Серед інших муколітиків ЕВКАБАЛ ${ }^{\circledR}$ САШЕ відрізняє висока німецька якість, засвідчена сертифікатом GMP (Good Manufacturing Practic) європейського зразка, та найкраще співвідношення ціна/якість. Препарат входить до Переліку лікарських засобів, дозволених до застосування в Україні, які відпускаються без рецептів з аптек та їх структурних підрозділів (наказ Міністерства охорони здоров'я України від 02.04.2018 р. № 599).

\section{Список використаної літератури}

Беляева Л.Е., Шебеко В.И., Солодков А.П. (2008) Редокс-зависимые механизмы действия $\mathrm{N}$-ацетилцистеина. Вест. Витебского гос. мед. универ., 7(4): $5-15$

Компендиум - лекарственные препараты (2017) ЭВКАБАЛ ${ }^{\circledR}$ САШЕ (EUCABAL ${ }^{\circledR}$ SACHET) (https://compendium.com.ua/info/339085/evkabal-supsup-sashe).

Міністерство охорони здоров'я України (2018) Наказ Міністерства охорони здоров'я України від 02.04.2018 р. № 599 «Про затвердження Переліку лікарських засобів, дозволених до застосування в Україні, які відпускаються без рецептів з аптек та їх структурних підрозділів» (https:// zakon.rada.gov.ua/laws/show/z0494-18)

Соодаева С.К., Никитина Л.Ю., Климанов И.А. (2015) Механизмы развития оксидативного стресса под воздействием аэрополлютантов окружающей среды: потенциал средств антиоксидантной защиты. Пульмонология, 25(6): 736-742.
Amaral E.P., Conceição E.L., Costa D.L. et al. (2016) N-acetyl-cysteine exhibits potent anti-mycobacterial activity in addition to its known anti-oxidative functions. BMC Microbiol., 16(1): 251.

Backer J.D., Vos W., Holsbeke C.V. et al. (2013) Double blind, randomized, two-way crossover, pilot study to assess the effect of high dose $\mathrm{N}$ acetylcysteine on airway geometry, inflammation and oxidative stress in copd patients using functional respiratory imaging. Am. J. Resp. Crit. Care Med., 187: A2447.

Behr J., Demedts M., Buhl R. et al.; IFIGENIA study group (2009) Lung function in idiopathic pulmonary fibrosis - extended analyses of the IFIGENIA trial. Respir. Res., 10: 101.

Bustos T.C., Garigliany M. (2016) N-acetylcysteine: an old drug with variable anti-influenza properties. J. Controvers. Biomed. Res., 2(1): 1-8.

Cai S., Chen P., Zhang C. et al. (2009) Oral N-acetylcysteine attenuates pulmonary emphysema and alveolar septal cell apoptosis in smoking-induced COPD in rats. Respirology, 14(3): 354-359.

Calzetta L., Matera M.G., Rogliani P., Cazzola M. (2018) Multifaceted activity of $\mathrm{N}$-acetyl-I-cysteine in chronic obstructive pulmonary disease. Expert Rev. Respir. Med., 12(8): 693-708.

Chalumeau M., Duijvestijn Y.C. (2013) Acetylcysteine and carbocysteine for acute upper and lower respiratory tract infections in paediatric patients without chronic broncho-pulmonary disease. Cochrane Database Syst. Rev., 5: CD003124.

Circu M.L., Aw T.Y. (2012) Glutathione and modulation of cell apoptosis. Biochim. Biophys. Acta., 1823(10): 1767-1777.

Conrad C., Lymp J., Thompson V. et al. (2015) Long-term treatment with oral $\mathrm{N}$-acetylcysteine: affects lung function but not sputum inflammation in cystic fibrosis subjects. A phase II randomized placebo-controlled trial. J. Cyst. Fibros., 14(2): 219-227.

Criner G.J., Bourbeau J., Diekemper R.L. et al. (2015) Prevention of acute exacerbations of COPD: American College of Chest Physicians and Canadian Thoracic Society Guideline. Chest, 147(4): 894-942.

Dauletbaev N., Fischer P., Aulbach B. et al. (2009) A phase II study on safety and efficacy of high-dose $\mathrm{N}$-acetylcysteine in patients with cystic fibrosis. Eur. J. Med. Res., 14(8): 352-358.

De Caro L., Ghizzi A., Costa R. et al. (1989) Pharmacokinetics and bioavailability of oral acetylcysteine in healthy volunteers. Arzneimittelforschung, 39(3): 382-386

Decramer M., Rutten-van Mölken M., Dekhuijzen P.N. et al. (2005) Effects of $\mathrm{N}$-acetylcysteine on outcomes in chronic obstructive pulmonary disease (Bronchitis Randomized on NAC Cost-Utility Study, BRONCUS): a randomised placebo-controlled trial. Lancet, 365(9470): 1552-1560.

Dekhuijzen P.N., van Beurden W.J. (2006) The role for N-acetylcysteine in the management of COPD. Int. J. Chron. Obstruct. Pulmon. Dis., 1(2): 99-106.

Dinicola S., De Grazia S., Carlomagno G., Pintucci J.P. (2014) $\mathrm{N}$-acetylcysteine as powerful molecule to destroy bacterial biofilms. A systematic review. Eur. Rev. Med. Pharmacol. Sci., 18(19): 2942-2948.

DrugBank (2018) Acetylcysteine (https://www.drugbank.ca/drugs/ DB06151).

Eklund A., Eriksson O., Håkansson L. et al. (1988) Oral N-acetylcysteine reduces selected humoral markers of inflammatory cell activity in BAL fluid from healthy smokers: correlation to effects on cellular variables. Eur. Respir. J., 1(9): 832-838.

Garozzo A., Tempera G., Ungheri D. et al. (2007) N-acetylcysteine synergizes with oseltamivir in protecting mice from lethal influenza infection. Int. J. Immunopathol. Pharmacol., 20(2): 349-354.

Geiler J., Michaelis M., Naczk P. et al. (2010) N-acetyl-L-cysteine (NAC) inhibits virus replication and expression of pro-inflammatory molecules in A549 cells infected with highly pathogenic H5N1 influenza A virus. Biochem. Pharmacol., 79(3): 413-420.

Global Initiative for Chronic Obstructive Lung Disease (2018) Global strategy for the diagnosis, management, and prevention of chronic obstructive pulmonary disease. 2019 Report (https://goldcopd.org/wp-content/uploads/2018/11/GOLD-2019-v1.7-FINAL-14Nov2018-WMS.pdf).

Hui D.S., Lee N., Chan P.K., Beigel J.H. (2018) The role of adjuvant immunomodulatory agents for treatment of severe influenza. Antiviral. Res., 150: 202-216.

Landini G., Di Maggio T., Sergio F. et al. (2016) Effect of high N-acetylcysteine concentrations on antibiotic activity against a large collection of respiratory pathogens. Antimicrob. Agents Chemother., 60(12): 7513-7517.

Mårtensson J., Gustafsson J., Larsson A. (1989) A therapeutic trial with $\mathrm{N}$-acetylcysteine in subjects with hereditary glutathione synthetase deficiency (5-oxoprolinuria). J. Inherit. Metab. Dis., 12(2): 120-130.

Martindale J.L., Holbrook N.J. (2002) Cellular response to oxidative stress: signaling for suicide and survival. J. Cell. Physiol., 192(1): 1-15.

Moon J.H., Choi Y.S., Lee H.W. et al. (2016) Antibacterial effects of $\mathrm{N}$-acetylcysteine against endodontic pathogens. J. Microbiol., 54(4): 322329 
NICE (2018) Chronic obstructive pulmonary disease in over 16s: diagnosis and management (https://www.nice.org.uk/guidance/ng115/chapter/Recommendations\#lung-surgery-and-lung-volume-reduction-procedures-Oral-mucolytic\%20 therapy).

Oka S., Kamata H., Kamata K. et al. (2000) N-acetylcysteine suppresses TNF-induced NF-kappaB activation through inhibition of lkappaB kinases. FEBS Lett, 472(2-3): 196-202.

Onk D., Özçelik F., Onk O.A. et al. (2018) Assessment of renal and hepatic tissue-protective effects of $\mathrm{N}$-acetylcysteine via ammonia metabolism: a prospective randomized study. Med. Sci. Monit., 24: 1540-1546.

Parasassi T., Brunelli R., Costa G. et al. (2010) Thiol redox transitions in cell signaling: a lesson from N-acetylcysteine. Sci. World J., 10: 1192-1202.

Pei Y., Liu H., Yang Y. et al. (2018) Biological activities and potential ora applications of $\mathrm{N}$-acetylcysteine: progress and prospects. Oxid. Med. Cell Longev., 2018: 2835787.

Pizzorno J.E., Katzinger J.J. (2012) Glutathione: physiological and clinical relevance. J. Rest. Med., 1(1): 24-37.

Poole P., Chong J., Cates C.J. (2015) Mucolytic agents versus placebo for chronic bronchitis or chronic obstructive pulmonary disease. Cochrane Database Syst. Rev., 7: CD001287.

Riise G.C., Qvarfordt I., Larsson S. et al. (2000) Inhibitory effect of Nacetylcysteine on adherence of Streptococcus pneumoniae and Haemophilus influenzae to human oropharyngeal epithelial cells in vitro. Respiration, 67(5): 552-558.

Roy R., Tiwari M., Donelli G., Tiwari V. (2018) Strategies for combating bacterial biofilms: A focus on anti-biofilm agents and their mechanisms of action. Virulence, 9(1): 522-554.

Sadowska A.M. (2012) N-Acetylcysteine mucolysis in the management of chronic obstructive pulmonary disease. Ther. Adv. Respir. Dis., 6(3): 127-135.

Stav D., Raz M. (2009) Effect of N-acetylcysteine on air trapping in COPD: a randomized placebo-controlled study. Chest, 136(2): 381-386.

Stey C., Steurer J., Bachmann S. et al. (2000) The effect of oral N-acetylcysteine in chronic bronchitis: a quantitative systematic review. Eur. Respir. J. 16(2): 253-262.

Teskey G., Cao R., Islamoglu H. et al. (2018) The Synergistic effects of the glutathione precursor, NAC and first-line antibiotics in the granulomatous response against Mycobacterium tuberculosis. Front. Immunol., 9: 2069.

Tirouvanziam R., Conrad C.K., Bottiglieri T. et al. (2006) High-dose oral $\mathrm{N}$-acetylcysteine, a glutathione prodrug, modulates inflammation in cystic fibrosis. Proc. Natl. Acad. Sci. USA, 103(12): 4628-4633.

Tse H.N., Raiteri L., Wong K.Y. et al. (2013) High-dose N-acetylcysteine in stable COPD: the 1-year, double-blind, randomized, placebo-controlled HIACE study. Chest, 144(1): 106-118.

Valdivieso A.G., Dugour A.V., Sotomayor V. et al. (2018) N-acetyl cysteine reverts the proinflammatory state induced by cigarette smoke extract in lung Calu-3 cells. Redox Biol., 16: 294-302.

WHO (2017) WHO Model List of Essential Medicines (http://apps.who.int/iris/ bitstream/handle/10665/273826/EML-20-eng.pdf).

Yan X., Song Y., Shen C. et al. (2017) Mucoactive and antioxidant medicines for COPD: consensus of a group of Chinese pulmonary physicians. Int. J. Chron. Obstruct. Pulmon. Dis., 12: 803-812.

Zafarullah M., Li W.Q., Sylvester J., Ahmad M. (2003) Molecular mechanisms of $\mathrm{N}$-acetylcysteine actions. Cell Mol. Life Sci., 60(1): 6-20.

Zhang Q., Ju Y., Ma Y., Wang T. (2018) N-acetylcysteine improves oxidative stress and inflammatory response in patients with community acquired pneumonia: A randomized controlled trial. Medicine (Baltimore), 97(45): e13087.

Zheng J.P., Wen F.Q., Bai C.X. et al.; PANTHEON study group (2014) Twice daily $\mathrm{N}$-acetylcysteine $600 \mathrm{mg}$ for exacerbations of chronic obstructive pulmonary disease (PANTHEON): a randomised, double-blind placebo-controlled trial. Lancet Respir. Med., 2(3): 187-194.

Zuin R., Palamidese A., Negrin R. et al. (2005) High-dose N-acetylcysteine in patients with exacerbations of chronic obstructive pulmonary disease. Clin. Drug Investig., 25(6): 401-408.

\section{Мукорегулятор, антиоксидант, пневмопротектор - современное представление о месте ацетилцистеина в терапии заболеваний респираторной системы}

\section{В.Б. Николаенко}

Резюме. Накопленные за последние десятилетия данные экспериментальных и клинических исследований позволили существенно расширить представления о механизмахреализации положительных эффектов $N$-ацетилцистеина при патологии респираторной системы. Плейотропный эффект препарата в первую очередь связан с антиоксидантным действием: прямым, реализуемым благодаря наличию в молекуле тиольной групы, и непрямым, обусловленным повышением уровня глутатиона - ключевого регулятора редокс-состояния клеток. Кроме того, $N$-ацетилцистеин оказывает мукорегуляторное, противовоспалительное, пневмопротекторное, антитоксическое, антимикробное действие. При острых и хронических заболеваниях респираторной системы, сопровождающихся образованием густой и гнойной мокроты, N-ацетилцистеин способствует улучшению функции легких, положительной динамике клинических проявлений, снижению частоты обострений хронических респираторных заболеваний, а также улучшает физическую работоспособность и качество жизни пациентов. Антитоксический, нефро- и гепатопротекторный эффекты и особенности фармакокинетики $N$-ацетилцистеина определяют его хорошую переносимость и низкую частоту побочных реакций даже при длительном приеме в высоких дозах.

Ключевые слова: $N$-ацетилцистеин, респираторная система, мокрота, оксидативный стресс, муколитик, антиоксидат, пневмопротекция, воспаление, бронхит, пневмония, хроническая обструктивная болезнь легких, муковисцидоз, фиброзирующий альвеолит, туберкулез.

\section{Mucoregulator, antioxidant, pneumoprotector - a modern conception of the role of acetylcysteine in treatment of respiratory system diseases \\ V.B. Nikolaienko}

Summary. Accumulated over the past decades data of experimental studies and clinical trials significantly expanded the understanding of mechanisms of $\mathrm{N}$-acetylcysteine positive action in patients with pathology of respiratory system. $\mathrm{N}$-acetylcysteine has been reported to have pleiotropic effect, closely connected with antioxidant action: direct - that is realized by thiol group, and indirect - due to increasing of intracellular glutathione levels, thus regulating of intracellular redox status. Moreover, $N$-acetylcysteine has muco-regulatory, anti-inflammatory, pneumo-protective, antiinfective action. In acute and chronic respiratory system diseases with thick and purulence sputum $\mathrm{N}$-acetylcysteine benefits in positive dynamics of clinical manifestation, attenuates the lung injury and improves lung function, decreases the frequency of acute exacerbations as well as improves the physical performance and quality of life. Good tolerability and low incidence of adverse reactions, even observed during the long-term administration in high doses, can be explained by the antitoxic, nephro- and hepatoprotective effects and special pharmacokinetic characteristics of $\mathrm{N}$-acetylcysteine.

Key words: $N$-acetylcysteine, respiratory system, sputum, oxidative stress, mucolytic, antioxidant, pneumoprotection, inflammation, bronchitis, pneumonia, chronic obstructive pulmonary disease, cystic fibrosis, fibrous alveolitis, tuberculosis. 